\title{
Problematika Pemberdayaan Masyarakat Miskin
}

\author{
Muhammad Haris \\ Prodi Pengembangan Masyarakat Islam UIN Sutan Syarif Kasim Riau \\ (E-mail: mhd.haritsyah@gmail.com)
}

\begin{abstract}
Purpose of the study was to determine the problematics empowering poor. Research uses the literature review method, collecting data using a literacy analysis related to the empowerment process and observing empowerment programs. Results of the study explained that the problem of empowering poor people occurred in empowering time efficiency, understanding the empowerment programs. The factors causing these problems are: a). the lack of synchronization between central and practitioner empowerment planning. b). not yet in accordance with the application of the empowerment method in the midst of diversity. c). the use of the old paradigm in community empowerment. d). understanding of cultural values that are cloused.
\end{abstract}

Keywords: Problems, Empowerment, Poor

Abstrak: Tujuan penelitian ini untuk mengetahui problematika pemberdayaan masyarakat miskin. Penelitian menggunakan metode kajian pustaka, pengumpulan data terkait menggunakan analisis literasi yang berkaitan dengan proses pemberdayan dan melakukan observasi pada program-program pemberdayaan. Hasil penelitian menjelaskan problematika pemberdayaan masyarakat miskin terjadi pada efisiensi waktu pemberdayaan, pemahaman paradigma pemberdayaan, penggunaan metode pemberdayaan, penggunaan materi pemberdayaan, program pemberdayaan tidak berkelanjutan. Adapun faktor penyebab problematika tersebut yaitu: a). belum singkronnya perencanaan pemberdayaan pusat dan praktisi. b). belum sesuai penerapan metode pemberdayaan di tengah keberagaman. c). penggunaan paradigma lama dalam pemberdayaan masyarakat. d). pemahaman nilai budaya yang tertutup.

Kata Kunci: Problematika, Pemberdayaan, Masyarakat Miskin 
47 Muhammad Haris, Problematika Pemberdayaan Masyarakat Miskin Jurnal At-Taghyir : Jurnal Dakwah dan Pengembangan Masyarakat Desa Volume 2 Nomor 1 Desember 2019, h. 46-63

\section{A. Pendahuluan}

Beberapa problem pemberdayaan masyarakat belakangan ini adalah tidak sistinable (berkelanjutan). ${ }^{1}$ Pemerintah berdalih menjalankan semua program pemberdayaan telah sesuai standar dan memperhatikan kebutuhan masyarakat, tetapi semua upaya tersebut belum memberikan kontribusi yang memadai. Hal ini disebabkan oleh tidak adanya upaya lanjutan dalam memberdayakan masyarakat. ${ }^{2}$ Semestinya pemberdayaan masyarakat adalah sebuah proses memberikan daya atau kemampuan dari yang memiliki daya kepada yang memerlukan atau menerimanya. ${ }^{3}$ Berdasarkan penjelasan tersebut dapat dijelaskan maksud proses ialah adanya upaya, cara, usaha dan tahapan pemberdayaan untuk merubah tarap hidup masyarakat agar menjadi lebih berdaya dan mandiri dengan cara menggerakkan, melatih dan memotivasi masyarakat agar mereka menggali potensi diri sendiri dan berani mengambil keputusan dalam rangka mencapai kesejahteraan.

Selanjutnya pemberdayaan juga suatu proses untuk meningkatkan harkat dan martabat masyarakat yang dalam kondisi sekarang tidak berdaya. ${ }^{4}$ Pendapat tersebut menerangkan bahwa dalam pemebrdayaan ada proses belajar. Proses ini menjelaskan adanya tahapan-tahapan sistematis dalam kerangka kerja. Ambar Teguh Sulistiyani ${ }^{5}$ menjelaskan tahap tersebut dengan cara memunculkan kesadaran dan sikap pedulian, harapannya termotivasi untuk meningkatkan kualitas diri. Selanjutnya melatih terampil dan memberikan ide-ide serta gagasan-gagasan agar memiliki wawasan yang luas sehingga berpartisipasi dalam pembangunan. Seterusnya meyakinkan masyarakat bahwa potensi yang dimiliki adalah bakat yang terbarukan yang akan membawa mereka menjadi mandiri.

Urgensi penyadaran dalam pemberdayaan masyarakat adalah untuk menyadarkan masyarakat akan kebutuhannya, kemampuan dan masalah yang dihadapi. hlm. 131

${ }^{1}$ Chabib Soleh, Dialektika Pembangunan dengan Pemberdayaan, (Bandung: Fokusmedia, 2014),

2 Aprillia Theresia, Dkk, Pembangunan Berbasis Masyarakat, (Bandung: Alfabeta, 2014) hlm. 108

${ }^{3}$ Ambar Teguh Sulistiyani, Kemitraan dan Model-Model Pemberdayaan, (Yogyakarta: Gava Media, 2004), hlm. 77

${ }^{4} \mathrm{Abu}$ Huraerah, Pengorganisasian \& Pengembangan Masyarakat, Model \& Strategi Pembangunan Berbasis Kerakyatan, (Bandung: Humaniora, 2011), hlm. 101

${ }^{5}$ Ambar Teguh Sulistiyani, op.cit., hlm. 83 
48 Muhammad Haris, Problematika Pemberdayaan Masyarakat Miskin Jurnal At-Taghyir : Jurnal Dakwah dan Pengembangan Masyarakat Desa Volume 2 Nomor 1 Desember 2019, h. 46-63

Terkait hal ini tepat sekali seperti paparan Aziz Muslim ${ }^{6}$ yang menyatakan masyarakat yang sadar adalah masyarakat memahami potensi, hak dan tanggungjawabnya. Penjelasan ini dapat dipahami, dengan terbentuknya sikap sadar akan potensi dan kebutuhan yang dibutuhkan dapat mendorong masyarakat berinovasi, melakukan upayaupaya baru dan melakukan usaha secara mandiri untuk memenuhi kebutuhannya. Ketika hal ini sudah terjadi berarti mereka sudah berdaya.

Untuk mencapai kondisi yang diinginkan, dibutuhkan perencanaan kegiatan yang mengarah kepada kondisi ideal dimaksud. Perencanaan atas kegiatan sering tidak membutuhkan waktu yang singkat. Dibutuhkan waktu yang lama, bertahap untuk mencapai perubahan. Kegiatan yang dilakukan dalam mencapai perubahan itu disebut proses. Proses adalah serangkaian tindakan yang dilakukan dalam upaya mencapai hasil yang diinginkan. Proses yang dijalankan menciptakan perubahan yang direncanakan. Ada program-program pemerintah dalam memberdayakan masyarakat terkesan seperti merubah keadaan kepada kehendak yang diinginkan dengan berbagai macam bujukan dan lobi-lobi, sehingga tercipta kondisi yang diinginkan tetapi disisi lain memunculkan persoalan lain seperti tidak menjawab persoalan yang ada dan tidak mejawab kebutuhan masyarakat. Hal tersebut menunjukan perbedaan dalam memahami paradigma pemberdayaan itu sendiri. Penjelasan Totok Mardikanto ${ }^{7}$ perubahan terencana dalam pemberdayaan dapat dilakukan dalam dua bentuk, seperti: Pertama, perubahan yang dipaksakan atau bujukan. Kedua, perubahan melalui pembelajaran. Pernyataan ini menjelaskan hal yang menjadi prioritas ingin dicapai dari proses pemberdayaan. Kelompok pertama dari proses pemberdayaan lebih memprioritaskan hasil dan kelompok kedua dari proses pemberdayaan memprioritaskan proses.

Kelompok yang memprioritaskan hasil mengutamakan tindakan pemaksaan atau bujukan, agar situasi yang diinginkan tercapai dalam waktu yang singkat. Perubahannya akan terus bertahan jika sikap paksa masih terus dilakukan. Jika tidak kondisi kembali kepada sediakala. Selanutnya kelompok yang memprioritaskan proses mengutamakan kegiatan belajar untuk mencapai tujuan yang diinginkan. Proses belajar membutuhkan waktu yang lama, melewati berbagai tahapan yang sistematis dan perubahan yang

\footnotetext{
${ }^{6}$ Aziz Muslim, Metodologi Pengembangan Masyarakat,(Yogyakarta: Teras, 2009), hlm. 5

7 Totok Mardikanto, Pemberdayaan Masyarakat Dalam Perspektif Kebijakan Publik. (Bandung:
} Albeta, 2013), hlm. 67 
49 Muhammad Haris, Problematika Pemberdayaan Masyarakat Miskin Jurnal At-Taghyir : Jurnal Dakwah dan Pengembangan Masyarakat Desa

Volume 2 Nomor 1 Desember 2019, h. 46-63

terjadi tidak instan. Terkadang memunculkan kebingungan dan kebosanan. Tetapi hasil yang dicapai lestari.

Berdasarkan pendapat dua kelompok tersebut Randy R Wrihatnolo ${ }^{8}$ mengatakan, pemberdayaan adalah proses dan proses itu membaikan. Proses bukan terjadi dengan cepat, tetapi rangkaian peristiwa dalam waktu yang panjang. Sehingga tidak dapat dikatakan pemberdayaan terjadi dalam waktu yang singkat. Ditegaskan pemberdayaan adalah sebuah proses alamiah, artinya sebuah proses yang ditujukan seperti proses perkebangan manusia sampai dewasa dan mencapai mandiri. Dari penjelasan tersebut dapat dipahami perubahan yang direncanakan dalam pemberdayaan mementingkan proses dan tujuan yang dicapai. Proses merupakan langkah dan kegiatan yang tepat dalam mencapai tujuan. Ketika proses yang dilakukan sempurna maka hasilnya akan sempurna. Hasil yang dicapai dari pemberdayaan tidak serta merta langsung dilepas untuk menjadi mandiri, butuh pendampingan agar tidak kembali pada kondisi semula. Tindakan ini berorientasi pada kesempurnaan hasil. Jadi dalam permberdayaan proses dan hasil dua hal yang menjadi penting untuk diperhatikan, untuk mencapai masyarakat yang berdaya.

Persoalan kemiskinan masyarakat desa dalam prasangka adalah masyarakat yang terbelakang dan tidak memeliki apa-apa. ${ }^{9}$ Sebetulnya mereka mimiliki potensi berupa lahan yang bisa digarap dan keterampilan lainnya, melestarikan energi, tepat guna terhadap aset yang dimiliki untuk memperoleh kesejahteraan. ${ }^{10}$ Banyak diantara mereka terjebak oleh pemikirannya. ironinya pola fikir tersebut dianggap benar oleh sebagian kelompok mereka karena rasa persamaan. Beberapa pola fikir tersebut, seperti mereka sering mengeluhkan biaya atau modal yang tidak cukup untuk melakukan sesuatu. Membuat usaha ini dan itu semuanya sulit, tidak berani membuat keputusan sendiri, merasa nyaman dengan situasi yang ada meskipun kondisi tersebut tidak berkecukupan, meyakini bahwa kemiskinan diterima sebagai sebuah nasib. Pola pemikiran tersebut kebanyakan sudah tertanam dalam diri dan menjadi sebuah kebiasaan yang sulit dirubah.

\footnotetext{
${ }^{8}$ Randy R Wrihatnolo, Manajemen Pemberdayaan, (Jakarta: PT Alex Media Komputinda, 2002), hlm. 8

${ }^{9}$ Robert Chambers, Pembangunan Desa, (Jakarta : LP3ES, 1987), hlm. 99 hlm. 51

${ }^{10}$ Sunyoto Usman, Esai-Esai Sosiologi Perubahan Sosial, (Yogyakarta : Pustaka Pelajar, 2015),
} 
50 Muhammad Haris, Problematika Pemberdayaan Masyarakat Miskin Jurnal At-Taghyir : Jurnal Dakwah dan Pengembangan Masyarakat Desa Volume 2 Nomor 1 Desember 2019, h. 46-63

Berdasarkan fenomena tersebut di atas, penelitian ini mencoba untuk menjelaskan problematika pemberdayaan masyarakat miskin dengan fokus utama permasalahan yang akan dikaji adalah apa saja problematika pemberdayaan masyarakat miskin dan apa saja faktor penyebab problematika pemberdayaan masyarakat.

\section{B. Kajian Terdahulu}

Penelitian ini melihat beberapa perspektif dan berbagai macam ulasan dan analisa dengan mengacu kepada penelitian yang pernah dilakukan oleh beberapa peneliti sebelumnya dengan tema serupa, antara lain :

1. Dimas Alif Budi N, M. Saleh Soeaidy dan Minto Hadi ${ }^{11}$ tulisan mereka menjelaskan tentang inplementasi program pemberdayaan masyarakat melalui pelatihan keterampilan dasar ada 4 jenis pelatihan yaitu pelatihan makanan, handycraft, menjahit, dan aneka usaha dengan 9 sub pelatihan yang dilaksanakan. Namun dalam realisasinya terjadi problematika, capaian program belum mencapai sasaran, sementara tahapan-tahapan pemeberdayaan sudah sesuai standar operasional program. selanjutnya faktor pendukung adalah adanya agen koordinasi yang baik antar pihak dari atas ke bawah dan sebaliknya. Adapun faktor penghambat kurangnya kesadaran peserta dalam mengikuti proses pelatihan keterampilan. Hal ini disebabkan adanya tujuan peserta pelatihan yang berbedabeda.

2. Rina Hardi ${ }^{12}$ tujuan penelitiannya mengungkapkan terdapat dua opini masyarakat yaitu opini positif dan negatif. Adapun opini masyarakat seperti, Belief (kepercayaan mengenai sesuatu) masyarakat yang mengikuti pelatihan percaya dan mendukung berjalannya program pelatihan. Pembentukan opini masyarakat melalui Attitude (sikap) masyarakat tidak tenang selama mengikuti program tersebut karena teringat akan nasib keluarga yang ditinggalkan. Kemudian Perseption (persepsi) dipengaruhi latar belakang budaya, pengalaman masa lalu, keyakinan nilai-nilai dan berita-berita yang berkembang tentang P4S. Selanjutnya faktor yang mendorong

${ }^{11}$ Dimas Alif Budi N dan M. Saleh Soeaidy, Minto Hadi, Implementasi Program Pemberdayaan Masyarakat Melalui Pelatihan Keterampilan Dasar, (Jurnal Administrasi Publik (JAP)), Vol. 1, No. 5, hlm. 862-871

12 Rina Hardi, Opini Masyarakat Dalam Program Pusat Pelatihan Pertanian Pedesaan dan Swadaya (P4S) Pemerintah Kabupaten Kampar, (Jurnal Online Mahasiswa FISIP, Volume 1, No. 2 Oktober 2014), hlm. 1-12 
51 Muhammad Haris, Problematika Pemberdayaan Masyarakat Miskin Jurnal At-Taghyir : Jurnal Dakwah dan Pengembangan Masyarakat Desa

Volume 2 Nomor 1 Desember 2019, h. 46-63

pembentukan opini masyarakat dalam program P4S Pemerintah Kabupaten Kampar melalui penyebaran informasi menggunakan media, diantaranya melalui Riau Pos, Haluan Riau, dll.

3. Muhammad Haris ${ }^{13}$ dalam peneltiannya mengungkapkan Pemberdayaan masyarakat melalui program P4S mengalami berbagai problem. Diantara beberapa problem tersebut, salah satunya ialah belum adanya petani RTMPE pascapelatihan. Hasil penelitian menjelaskan proses pelaksanaan pelatihan: pertama, pelaksanaan pelatihan mengalami kendala yang signifikan. Hal ini terlihat dari: a). Proses penyadaran diganti dengan perekrutan peserta oleh Kades. b). Proses transformasi secara kolektif, tetapi efisiensi waktu pelatihan kurang tepat. c). Proses advokasi belum dilakukan. Kedua, metode yang digunakan kurang menjawab permasalahan, peserta hanya mendapatkan penataan dan pengalaman baru. Ketiga, materi pelatihan dipaksakan, terlihat pada setting program pelatihan tanpa memahami permasalahan masyarakat. Keempat, respon peserta terbagi dua, yaitu: Respon positif, peserta percaya program ini tepat dilakukan untuk petani Kampar. Respon negatif, pesrta aktif mengikuti proses pelatihan hanya menerapkan ilmu sebagian dan peserta tidak aktif mengikuti pelatihan. Kemudian output pelatihan belum mencapai tujuan. Terlihat pada kondisi peserta tidak berubah prapelatihan dan pascapelatihan serta belum dilakukan pendampingan. Selanjutnya problematika pelaksanaan pelatihan Pertama,efisiensi waktu pelatihan yang dilematis. Kedua, paradigma pemberdayaan menyamaratakan kriteria kemiskinan. Ketiga, metode pemberdayaan tidak memperhitungkan perbedaan masyarakat. Keempat, materi pelatihan dipaksakan tanpa memperhatikan masalah dan kebutuhan masyarakat. Kelima, program pemberdayaan tidak berkelanjutan.

4. Yefni dan Muhammad Haris ${ }^{14}$ Penelitian ini bertujuan untuk mengetahui implemetasi Program Penyediaan Air Minum dan Sanitasi Berbasis Masyarakat (PAMSIMAS) pada masyarakat Desa Padang Mutung. Hasil penelitian menjelaskan Program PAMSIMAS melakukan sosialisasi sanitasi lingkungan yaitu,

\footnotetext{
13 Muhammad Haris, Problematika Pemberdayaan Masyarakat Melalui Program P4S Karya Nyata Pemerintah Kabupaten Kampar, (Tesis: UIN Imam Bonjol Padang, 2016)

${ }^{14}$ Yefni, Muhammad Haris. (2019). Pemberdayaan Lingkungan Melalui Program Penyediaan Air Minum dan Sanitasi Berbasis Masyarakat(PAMSIMAS) Desa Padangmutung. Jurnal Masyarakat Madani, 4(1), hlm. $16-25$
} 
52 Muhammad Haris, Problematika Pemberdayaan Masyarakat Miskin Jurnal At-Taghyir : Jurnal Dakwah dan Pengembangan Masyarakat Desa

Volume 2 Nomor 1 Desember 2019, h. 46-63

penyampaian materi dan pemahaman kondisi limgkungan Desa Padang Mutung kemudian melakukan aksi praktis bersih-bersih perkarangan rumah hingga DAS. Ke dua, melakukan kegiatan praktis yaitu, partisipasi aktif masyarakat menggali dan menyambung pipa-pipa air bersih ke rumah warga. Selanjutnya kondisi lingkungan masyarakat pra-Program PAMSIMAS membutuhkan perbaikan sanitasi yang ditandai dengan macetnya saluran irigasi dan tercemarnya aliran sungai akibat limbah rumah tangga. Adapun kondisi lingkungan masyarakat pascaprogram PAMSIMAS, sanitasi lingkungan menjadi lebih baik, ditandai dengan kepedulian masyarakat terhadap sampah, aktifitas MCK yang baik dan masyarakat memperoleh air dengan mudah.

5. Susi ratnawati ${ }^{15}$ penelitiannya menjelaskan secara komprehansif terkait model pemberdayaan perempuan miskin pedesaan melalui pengembangan kewirausahaan untuk meningkatkan taraf hidup. Model pemberdayaan perempuan miskin perdesaan melalui pengembangan kewirausahaan dengan cara pendekatan kelompok dan diversifikasi usaha, Upaya ini dilakukan untuk meningkatkan kesejahteraan dan keberdayaan perempuan miskin di pedesaan menyangkut pada persoalan bagaimana upaya pemberdayaan perempuan miskin perdesaan melalui kewirausahaan dapat menjamin para pelaku ekonomi rakyat memperoleh apa yang menjadi hak mereka, khususnya kesejahteraan dan taraf kehidupan yang layak.

\section{Proses Pemberdayaan Masyarakat}

Untuk mencapai kondisi yang diinginkan, dibutuhkan perencanaan kegiatan yang mengarah kepada kondisi ideal dimaksud. Perencanaan atas kegiatan dibutuhkan waktu yang lama, bertahap untuk mencapai perubahan dan disebut proses. Menurut Totok Mardikanto ${ }^{16}$ perubahan terencana dalam pemberdayaan dapat dilakukan dalam dua bentuk, seperti: Pertama, perubahan yang dipaksakan atau bujukan. Kedua, perubahan melalui pembelajaran. Kelompok pertama memprioritaskan hasil dan kelompok kedua proses.

Kelompok yang memprioritaskan hasil mengutamakan tindakan pemaksaan atau bujukan, agar situasi yang diinginkan terwujud dengan cepat. Tetapi perubahan yang

15 Susi Ratnawati. (2011). Model Pemberdayaan Perempuan Miskin Pedesaan Melalui Kewirausahaan. Jurnal Kewirausahaan, 5 (2), hlm. 1- 10

${ }^{16}$ Totok Mardikanto, op.cit., hlm. 67 
53 Muhammad Haris, Problematika Pemberdayaan Masyarakat Miskin Jurnal At-Taghyir : Jurnal Dakwah dan Pengembangan Masyarakat Desa

Volume 2 Nomor 1 Desember 2019, h. 46-63

dihasilkan akan terus terjaga jika pemaksaan terus dilakukan. Selanutnya kelompok yang memprioritaskan proses mengutamakan kegiatan belajar untuk mencapai tujuan yang diinginkan. Tetapi hasil yang dicapai lestari. Jadi dalam permberdayaan proses dan hasil dua hal yang menjadi penting diperhatikan untuk mencapai masyarakat yang berdaya.

Menurut Ambar Taguh Sulistiyani ${ }^{17}$ proses pemberdayaan tersebut dijelaskan seperti:Pertama, tahap persiapan pemberdayaan, lingkup kerjanya meliputi pembentukan perilaku sadar. Tahapan ini pihak yang berdaya berusaha menciptakan prakondisi. Supaya dapat memfasilitasi berlangsungnya proses pemberdayaan yang efektif. Terkadang, proses penyadaran dipahami sebagai sesuatu yang beda dari konsep pemberdayaan sebagai proses penyadaran. Pihak pengelola memahami proses penyadaran sebagai bentuk pengenalan inovasi program kepadamasyarakat. Tetapi dari sisi pemberdayaan lebih kepada aksi penyadaran sikap, sehingga masyarakat merasa termotivasi untuk memperbaiki diri. ${ }^{18}$ Ada tepatnya seperti yang dijelaskan oleh Totok Mardikanto $^{19}$ bahwa dalam setiap upaya pemberdayaan harus terkandung upaya pembelajaran untuk mencapai kemandirian. Dari penjelasan tersebut dapat dipahami bahwa kemandirian masyarakat tercapai apabila melewati proses yang bertahap, bukan melewati proses yang instan dengan pemberian intensif.

Kedua, proses transformasi pengetahuan dan. Masyarakat menjalani proses belajar tentang pengetahuan dan keterampilan yang memiliki relevansi memecahkan permasalahan yang dialami Berkaitan dengan penjelasan di atas, tujuan pemberdayaan yang dijelaskan oleh Aziz Muslim, ${ }^{20}$ membangun kesejahteraan masyarakat tanpa meningkatkan pengabdian diri kepada Allah berarti membangun kemajuan material yang dapat menjerumuskan pada mala petaka kemanusiaan. Sebaliknya membangun penghambaan diri kepada Allah dengan melupakan tugas membangun kesejahteraan dapat menjadikan kehidupannya yang hampa, kurang bermanfaat dan sia-sia belaka.

Ketiga, tahap penguatan atau peningkatan intelektualitas dan keterampilan melalui advokasi, supaya mereka dapat membentuk usaha kemandirian. Kemandirian

\footnotetext{
${ }^{17}$ Ambar Teguh Sulistiyani, op.cit, hlm.83-84

${ }^{18}$ Ambar Teguh Sulistiyani, op.cit., hlm. 83

${ }^{19}$ Totok Mardikanto, op.cit., hlm. 67-68

${ }^{20}$ Aziz Muslim, op.cit., hlm. 6
} 
54 Muhammad Haris, Problematika Pemberdayaan Masyarakat Miskin Jurnal At-Taghyir : Jurnal Dakwah dan Pengembangan Masyarakat Desa

Volume 2 Nomor 1 Desember 2019, h. 46-63

tersebut ditandai dengan adanya inisiatif, melahirkan kreasi-kreasi dan melakukan inovasi-inovasi di lingkungannya. Selain itu juga menjembatani peserta dengan pemerintah dan lembaga pemberdayaan disamping juga memberikan solusi atas kendala yang dihadapi selama mereka memulai pola kehidupan baru. ${ }^{21}$ Pendampingan juga proses peningkatan kualitas agar masyarakat mencapai kemandirian. Kemandirian dapat dilihat dari kemampuan masyarakat memenuhi kebutuhannya, menciptaka peluang baru dalam memperoleh pendapatan dan mampu memperbaiki keadaan dari sebelumnya. Sebagaiamana dalam penjelasan terdahulu bahwa pencapaian dalam pemberdayaan masyarakat yaitu terbentuknya strukur masyarakat yang mencerminkan tumbuhnya kesadaran, semangat keswadayaan dan partisipasi. ${ }^{22}$

Sementara menurut Amrullah Ahmad, dikutip oleh Muhammad Sulthon, ${ }^{23}$ berusaha menjelaskan kerangka tahapan dakwah yang dilakukan oleh Rasulullah Saw untuk dipraktekkan pada proses pemberdayaan masyarakat, yaitu: Takwîn (Pembentukan masyarakat dakwah), Tandzîm (penataan dakwah), Pendelegasian (tahapan pelepasan dan kemandirian). Hal ini tampak setelah peristiwa haji Wada' masyarakat muslim berhasil mengembangkan wilayah Islam hingga afrika. Ini menunjukan sahabat berhasil meneruskan dakwah Nabi Muhammad Saw. ${ }^{24}$

\section{Hasil dan Pembahasan}

Semua program pemberdayaan masyarakat harus menjawab dan memecahkan permasalahan yang ada, bukan sebaliknya menambah permasalahan baru yang membuat keadaan semakin sulit. Program pemberdayaan memiliki tujuan. Secara umum memiliki tujuan untuk menciptakan kondisi yang berkembang, berdaya dan mandiri. Kondisi tersebut tampak dalam perubahan yang terjadi di masyarakat. Mengutip pendapat Totok Mardikato $^{25}$ perubahan dalam pemberdayaan itu seperti perubahan dalam pengetahuan, sikap dan keterampilan. Perubahan pada pengetahuan, membentuk sikap kewirausahaan yang berinovasi untuk memenuhi kebutuhan. Perubahan sikap, membentuk sikap professional yang terus mengembangkan keahlian sesuai kompetensi. Perubahan pada

\footnotetext{
${ }^{21}$ Totok Mardikanto, op.cit., hlm. 140

22 Zubaedi, Pengembangan Masyarakat, (Jakarta: Kencana, 2013), hlm. 5

${ }^{23}$ Muhammad Sulthon, Desain Ilmu Dakwah, Kajian Ontologis, Epistemologis dan Aksiologis, (Semarang : Wali Songo Press, 2003), hlm. 120

${ }^{24}$ Yusra Kilun, ed, Pengembangan Komunitas Muslim Kampung Badak Putih dan Kampung Duit, (Jakarta: UIN Syarif Hidayatullah, 2007), hlm. 76-77

${ }^{25}$ Totok Mardikanto,Op.Cit, hlm. 223
} 
55 Muhammad Haris, Problematika Pemberdayaan Masyarakat Miskin Jurnal At-Taghyir : Jurnal Dakwah dan Pengembangan Masyarakat Desa

Volume 2 Nomor 1 Desember 2019, h. 46-63

keterampilan, membentuk sikap mandiri yang berani mengambil keputusan untuk kehidupannya agar lebih baik.

Proses pemberdayaan menunjukkan rangkaian kegiatan yang runut, disusun sesuai urutan penangannya dalam mencapai kondisi yang diinginkan. Hasil yang ingin dicapai terciptanya sumber daya manusia yang berkualitas, misalnya dalam bidang pertanian, perikanan dan peternakan bahkan dalam bidang lainnya. Selain itu terbentuknya kelompok masyarakat secara swadaya. Selama kegiatan berlangsung, dimungkinkan terjadi berbagai problem menghambat tujuan akhir. Berbagai problem tersebu, juga menjadi problematika. Problematika merupakan suatu kondisi yang serba salah. Pengertian lain yang dapat dipahami ialah penyelesaian masalah yang tersulit. Maksud sulit yaitu diselesaikan dan tidak diselesaikan juga memunculkan masalah. Sesuai dengan pendapat Syukir ${ }^{26}$ problematika adalah kesenjagan antara harapan dan kenyataan yang diharapakan dapat dikurangi kesenjangannya, namun dalam kondisi yang lain menimbulkan kesenjangan baru. Dari uraian tersebut, problematika juga disebut permasalahan yang sudah lama terjadi, namun belum ada penyelesaian. Lamanya permasalahan tersebut, mengindikasikan sulitnya solusi untuk menjawab permasalahan itu. Setelah dilakukan pengamatan dan analisa kepada beberapa program pemberdayaan masayarakat mengindikasi banyaknya persoalan yang belum terselesaikan, disamping perencanaan meminimalisir persoalan kadangkala memunculkan persoalan baru yang menjadi dilema. Adapun berbagai problematika dalam proses pemberdayaan masyarakat dapat diuraikan sebagai berikut:

\section{Efisiensi Waktu Pelaksanaan Kegiatan}

Masyarakat miskin perlu diberdayakan agar memperoleh kehidupan yang lebih baik dan mandiri. ${ }^{27}$ Untuk mencapai kemandirian proses pemberdayaan dilakukan secara bertahap dan butuh waktu. Misalnya dalam suatu kondisi masyarakat mengikuti pelatihan meskipun tidak mendapatkan pengetahuan penuh satu siklus pertanian. Namun dalam kondisi yang lain masyarakat tidak mengetahui perkembangan terpenting dalam siklus pertanian. Sebaliknya panjangnya waktu pelatihan membuat masyarakat tidak tenang, kawatir dengan kondisi kebutuhan keluarga yang ditinggalkan dan meningglkan pelatihan disamping juga memperhitungkan besarnya anggaran yang

\footnotetext{
${ }^{26}$ Syukir, Dasar-Dasar Strategi Dakwah Islami, (Surabaya : Al-Ikhlas, 1983), hlm. 65

${ }^{27}$ Aziz Muslim, op.cit., hlm. 7
} 
56 Muhammad Haris, Problematika Pemberdayaan Masyarakat Miskin Jurnal At-Taghyir : Jurnal Dakwah dan Pengembangan Masyarakat Desa

Volume 2 Nomor 1 Desember 2019, h. 46-63

dikeluarkan. Akibatnya masyarakat yang mempraktekkan pengetahuan dan keterampilan mengalami permasalahan. Masih banyak siklus dalam pelatihan yang belum dimengerti, pelatihan sudah berakhir. Singkatnya sering waktu dalam program pemberdayaan bertentangan dengan pemenuhan kebutuhan masyarakat dan disisi lain waktu pelaksanaan program juga tidak memberikan pemahaman baik kepada masyarakat. Hal ini bisa disebabkan oleh pembiayaan dan lain-lain.

\section{Pemahaman Paradigma Pemberdayaan}

Paradigma pemberdayaan berorientasi pada potensi dan kemandirian sumber daya manusia. Namun dalam pemahamannya penyelenggara masih menggunakan paradigma lama yang beranggapan pendekatan pembangunan dan penggunaan teknologi yang berasal dari atas selalu dinilai baik. ${ }^{28}$ Selain itu, anggapan pemerintah kemiskinan sesuatu yang absolut dengan menyamakan kriterianya untuk semua masyarakat dalam menjalankan program pemberdayaan. Pada kondisi tertentu masyarakat bisa diarahkan dan diintervensi untuk masuk kedalam program pemberdayaan. Tetapi pada kondisi yang lain pascapemberdayaan masyarakat tidak mampu menjawab permasalahannya sendiri, ditambah lagi pradigma masyarakat pemberdayaan sebagai sebuah proses yang panjang dan tidak menjawab kebutuhan sekarang. Hal ini tampak dari penjelasan proses penyadaran terkadang diganti dengan cara yang lain-lain. Adakalanya pemerintah berdalih tidak percaya dengan tenaga penyuluh dan lain-lain. Penyuluhan dan penyadaran dilakukan dalam bentuk pengenalan program setelah masyarakat menjadi peserta. Selain itu, terkadang masyarakat juga diintervensi dengan pemberian intensif. Hal tersebut, bukan mengintervensi kesadaran, tetapi menyebabkan ketergantungan. Sebagaimana dalam penjelasan terdahulu bahwa pemberian intensif akan dapat mempengaruhi masyarakat untuk mengikuti pelatihan, tetapi tidak menjawab permasalahan yang sedang mereka hadapi.

\section{Penggunaan Metode Pemberdayaan}

Melihat kondisi masyarakat yang heterogen, tentu latar belakang masyarakat juga dari berbagai ragam profesis dan tidak hanya satu. Di satu sisi kondisi ini memberikan pengetahuan dan keterampilan bagi sebagian masyarakat meskipun dalam penerapannya hanya sebagian pengetahuan saja. Namun pada kondisi yang lain akan

\footnotetext{
${ }^{28}$ Totok Mardikanto, op.cit., hlm. 34
} 
57 Muhammad Haris, Problematika Pemberdayaan Masyarakat Miskin Jurnal At-Taghyir : Jurnal Dakwah dan Pengembangan Masyarakat Desa

Volume 2 Nomor 1 Desember 2019, h. 46-63

mengalami permasalahan pada masyarakat yang tidak mempunyai latar belakang yang berbeda. Apabila diterapkan misalnkan metode andragogi yang dimaksudkan bahwa peserta sudah memiliki pengetahuan dalam bidang pertanian. Peserta yang mempunyai latar belakang di luar pertanian mengalami permasalahan dalam prakteknya. Permasalahan tersebut seperti mereka tidak cepat mengerti dan memahami apa yang disampikan instruktur dalam waktu yang singkat dan cepat serta kurang motivasi dalam mendirikan usaha tani, karena pelatihan ini berbeda dengan profesi mereka sebelumnya. Akibatnya proses pelaksanaan pelatihan hanya menambah pengetahuan dan keterampilan, tetapi tidak menjawab permasalahan yang menjadi persoalan masyarakat. Akibatnya pascapelatihan peserta kembali menjalankan profesi semula. ${ }^{29}$

\section{Penggunaan Materi Pemberdayaan}

Materi pemberdayaan memberikan pengetahuan dan keterampilan masyarakat. Namun apabila melihat kondisi masayarakat memiliki latar belakang yang heterogen, memilih satu materi saja terkesan seperti dipaksakan. Di satu sisi masyarakat yang mempunyai latar belakang misalkan petani, hasilnya hanya menambah pengetahuan dan keterampilan, namun tidak mengubah sikap dan memecahkan permasalahan mereka. Padahal dalam teori pemberdayaan yang dilakukan harus mampu menjawab permasalahan sekarang dan akan datang yang dihadapi masyarakat. Sementara itu masyarakat yang memiliki latar belakang yang lain permasalahan mereka belum terjawab. Penyebabnya pemerintah tidak mengetahui kondisi dan permasalahan lapangan. Sehingga semua materi jika diterapkan kepada masyarakat yang mempunyai latar belakang yang berbeda, akan mengalami permasalahan. Lebih lanjut, ditambah lagi dengan sikap dan pola fikir peserta yang masih tertutup.

\section{Program Pemberdayaan Tidak Berkelanjutan}

Pemberdayaan masyarakat membangun sumber daya manusia yang berpengetahuan dan berketerampilan untuk mandiri dalam memenuhi kebutuhannya untuk mencapai kesejahteraan. ${ }^{30}$ Melihat proses pemberdayaan yang tidak sampai pada proses advokasi, terlihat masyarakat seperti dilatih, dipersuasi diberdayakan tetapi hanya bersifat semu. Dalam kondisi tertentu upaya ini memberikan daya melalui

\footnotetext{
${ }^{29}$ Muhammad Haris, Op.Cit, hlm. 143

${ }^{30}$ Setiana L, Teknik Penyuluhan dan Pemberdayaan Masyarakat, (Bogor: Bhalia Indonesia, 2005), hlm. 13
} 
58 Muhammad Haris, Problematika Pemberdayaan Masyarakat Miskin Jurnal At-Taghyir : Jurnal Dakwah dan Pengembangan Masyarakat Desa

Volume 2 Nomor 1 Desember 2019, h. 46-63

transfosmasi dalam bentuk pegetahuan dan keterampilan. Namun pada kondisi yang lain upaya ini tidak berlajut sampai pada tahap advokasi. Tahap ini semestinya mendampingi masyarakat dalam mejawab permasalahan sendiri agar mampu melakukan inovasi untuk memenuhi kebutuhan. Kenyataannya tidak terbentuk kelompok masyarakat secara swadaya.

Problematika pemberdayaan masyarakat bermula dari pemahaman paradigma pemberdayaan masyarakat yang menggunakan paradigma lama. Paradigma ini menyamaratakan semua permasalahan dalam masyarakat dan dibuatkan setting program untuk menanggulanginya. Anggapannya masyarakat pasti berubah dengan cara seperti ini, masyarakat butuh bantuan modal untuk mendirikan usaha. Asumsi tersebut tidak mungkin dilakukan karena masyarakat memilki latar belakang dan permasalahan yang berbeda-beda. Meskipun dalam satu wilayah yang sama, tetapi secara individu dan secara kolektif memiliki permasalahan yang berbeda dalam memenuhi kebutuhan. Satu model tidak bisa diterapkan pada semua masyarakat. Model tersebut hanya akan diterima oleh masyarakat yang berprofesi sama dengan model tersebut. Dampak dari pemahaman itu, mempengaruhi manajemen pelaksanaan, motode dan materi yang digunakan terkhusus pada proses pemberdayaan itu sendiri.

\section{Faktor-Faktor Penyebab Problematika Pemberdayaan Masyarakat}

Berbagai problematikan pemberdayaan muncul disebabkan oleh sebab yang memunculkannya. Kemunculannya akibat dari kesalahan dalam memahami proses pelaksanaan, terkhusus lagi kesalahan dalam memahami proses pemberdayaan. Berdasarkan pada proses pemberdayaan dan output pemberdayaan dapat dijelaskan faktor-faktor yang menjadi penyebab problematika pemberdayaan masyarakat, dapat dijelaskan sebagai berikut:

\section{a. Pelaksanaan Manajemen Pemberdayaan}

Manajemen pemberdayaan dapat dilihat pada konektifitasnya sistem pemberdayaan pusat dengan bawahan yang berjalan di tempat masing-masing. Situasi ini tampak belum adanya laporan permasalahan masyarakat dan usaha yang dilakukan masyarakat pascapemberdayaan. ${ }^{31}$ Hal tersebut mempersulit untuk mengetahui kondisi masyarakat dan permasalahanya. Permasalahan mendasarnya terletak pada strategi yang

\footnotetext{
${ }^{31}$ Hasil observasi, 20 Maret 2019
} 
59 Muhammad Haris, Problematika Pemberdayaan Masyarakat Miskin Jurnal At-Taghyir : Jurnal Dakwah dan Pengembangan Masyarakat Desa

Volume 2 Nomor 1 Desember 2019, h. 46-63

digunakan dalam pemberdayaan masyarakat. Kesalahan strategi menyebabkan pelaksana tidak mengetahui permasalahan masyarakat yang diubah. Selain itu juga akan salah dalam menggunakan metode dan materi dalam pemberdayaan. Kegiatan pemberdayaan yang dilakukan tanpa mengetahui akar permasalahan dan permasalahan yang harus diselesaikan adalah bentuk kegiatan yang tidak menjawab permasalahan.

\section{b. Pemilihan Metode Pemberdayaan}

Penerapan satu metode pemberdayaan pada semua masyarakat yang mempunyai latar belakang profesi berbeda menyebabkan terjadinya permasalahan dalam pemberdayaan masyarakat. Semestinya metode yang digunakan melihat kepada heterogennya masyarakat. Hal ini diketahui pengambil kebijakan menetapkan kriteria yang sama pada semua masyarakat dan tanpa mengetahui dengan pasti permasalahan dan kebutuhannya. Lebih lanjut ditegaskan pemberdayaan dilakukan kepada seluruh masyarakat berdomisili di suatu daerah, agar mendorong mereka memiliki usaha. Anggapan semua masyarakat disuatu wilayah itu mengalami permasalahan yang sama adalah suatu hal yang harus dijauhi. Misalnya masyarakat yang mempunyai latar belakang petani merasa tambahan pengetahuan dan keterampilan baru. Sementara masyarakat yang mempunyai latar belakang diluar pertanian, dasar pertanian jauh dari mereka. Mereka harus mulai dari awal dengan rinci sementara pelatihan yang dilakukan proses cepat.

\section{c. Penggunaan Materi Pemberdayaan}

Materi pemberdayaan menggunakan satu materi tertentu tanpa melihat sisi heterogennya masyarakat, terkesan pemaksaan terhadap materi pelatihan. asumsi yang digunakan menganggap kemiskinan bisa dikurangi jumlahnya, tetepi mengabaikan pada jawaban latar belakang masalah masyarakat yang heterogen. Seperti banyaknya masyarakat dalam program pemberdayaan datang dari utusan Kepala Desa yang sebelumnya mereka tidak mengetahui apapun. Proses yang demikian mengakibatkan ada yang mempraktekkan ilmunya dan di pihak lain ada juga yang tidak.

\section{d. Paradigma Pemberdayaan Masyarakat yang Digunakan}

Pemangku kebijakan menggunakan paradigma lama dalam proses pemberdayaan. Anggapan mereka dengan paradigma itu masalah kemiskinan dalam masayarakat akan terjawab. Sehingga jumlahnya secara kuantitatif dapat dikurangi. 
60 Muhammad Haris, Problematika Pemberdayaan Masyarakat Miskin Jurnal At-Taghyir : Jurnal Dakwah dan Pengembangan Masyarakat Desa

Volume 2 Nomor 1 Desember 2019, h. 46-63

Paradigma tersebut menganggap kemiskinan masyarakat di suatu daerah sebagai sesuatu yang absolut dan disamaratakan kriterianya. Berdasarkan kriteria tersebut disusun program pemberdayaan. Dalam realitasnya kemiskinan itu bersifat relatif, boleh jadi kemiskinan disuatu kelompok masayarakat baik diterapkan suatu program, tetapi dalam masyarakat yang lain belum tentu. Karena yang harus disepakati adalah pemahaman akar permasalahan masyarakat. Seyogyanya paradigma pengembagan masyarakat sudah bergeser dan memberikan kebebasan kepada masyarakat dengan seluas-luasnya. Sehingga dengan begitu masyarakat merasa dipentingkan dalam pemberdayaan. Selain itu mereka juga diikutsertakan dalam perencanan, pelaksanaan dan perumusan masalah yang dihadapi, dengan begitu masyarakat mengetahui pentingnya memperbaiki diri.

\section{e. Pemahaman Nilai Budaya}

Pemahaman nilai budaya juga menjadi faktor penyebab problematika pelatihan. Nilai tersebut melekat dalam diri masyarakat sebagai keberadaannya dalam sebuah kelompok masyarakat. Nilai tersebut bersifat mengikat kepada masyarakat. Nilai budya yang tidak memiliki jiwa keterbukaan terhadap hal-hal baru ditambah lagi berprasangka buruk terhadap nilai budaya lain menjadi penghambat pembangunan. Nilai budaya yang menjadi penyebab problematika tersebut adalah:

1) Sistem nilai dan kepercayaan

Masyarakat tidak mau merubah pola hidup yang sudah mereka jalani dan diyakini pola tersebut membuat mereka dalam posisi aman. Opini muncul dari adanya sebuah program pemerintah dalam bidang pemberdayaan. Opini masayarakat ada yang baik yaitu mengikuti semua proses dengan baik dan opini negatif yaitu tidak melaksanakan proses dengan baik. Artinya program pemberdayaan masyarakat melalui proses belajar untuk menumbuhkan keberdayaan. Ketika mencapai keberdayaan masyarakat disebut mandiri. Kemandirian masyarakat tampak dari kemandirian bersikap dan berperilaku, mampu mengambil keputusan dan berinovasi serta mempertahankan haknya. Tetapi tidak demikian halnya, masyarakat berpendapat pemberdayaan dalam bentuk proses pelatihan memakan waktu yang lama dan akan dipilih setelah berbagai program yang menjawab permasalahan ekonomi mereka.

2) Sikap tradisional yang berprasangka buruk terhadap hal-hal baru 
61 Muhammad Haris, Problematika Pemberdayaan Masyarakat Miskin Jurnal At-Taghyir : Jurnal Dakwah dan Pengembangan Masyarakat Desa Volume 2 Nomor 1 Desember 2019, h. 46-63

Sikap tradisional yang tertutup dengan dunia luar akan selalu menolak paham baru yang masuk. Sikap ini berhunbungan dengan mentalitas. Hal ini dapat dilihat pascapemberdayaan, mentalitas yang tidak baik bersumber dari kehidupan yang raguragu, kehidupan tanpa orientasi yang jelas dengan kondisi rumah tangga yang rentan tanpa penyangga apabila diguncang kebutuhan yang mendesak, tidak berani dalam mengambil keputusan untuk melakukan sebuah usaha dan peminjaman modal, masih takut gagal dalam usaha yang akan dijalankan dan berlebihan.

Berdasarkan penjelasan di atas, faktor penyebab problematika pemberdayaan masyarakat secara umum dibagi menjadi dua, yaitu faktor internal dan external. Faktor seperti yang disebutkan pertama berasal dari kebijakan pemerintah, seperti paradigma yang digunakan, pelaksanaan waktu dan penggunaan materi dan metode pemberdayaan. Faktor seperti yang disebutkan kedua berasal dari pemahaman nilai budaya masyarakat. Pemahaman nilai tersebut, seperti sistem nilai kepercayaan, pengaruh opini atau sudut pandang dan sikap tradisional. Hal tersebut menjadi faktor penyebab karena kebijakan dan pemahaman yang digunakan memunculkan permasalahan yang sulit.

Secara keseluruhan problematika pemberdayaan masyarakat berawal dari penggunaan paradigma lama dalam pemberdayaan. Hal ini untuk mengatasi permasalahan kemiskinan. Kebijakan tersebut menyamakan semua kriteria dan permasalahan kemiskinan yang dijawab dengan satu program. Padahal permasalahan masyarakat tidak sama, butuh penyelesaian berfokus pada satu permasalahan yang diimbangi dengan pembangunan dari sisi yang lain. Pemahaman paradigma tersebut, tampak dari proses penyadaran terkadang diganti dengan perekrutan oleh Kepala desa. Padahal proses penyadaran mendorong kesadaran masyarakat. Kesadaran masyarakat bukan berarti mengetahui tentang program pemberdayaan saja, tetapi lebih kepada kesadaran tentang kondisi dan permasalahan kemiskinan yang melekat pada masyarakat. Melalui kesadaran tersebut, akan tercipta dorongan ataupun motivasi dari dalam diri secara pribadi untuk memperbaiki keadaan. Sehingga perbaikan kualitas kehidupan diusahakan oleh mereka sendiri bukan orang lain. Karena perbaikan kualitas hidup hanya bisa diusahakan oleh masyarakat sendiri.

Kemudian tidak dilakukan proses pendampingan. Pendampingan dilakukan agar mereka tidak kembali menjadi seperti semula. Pemberdayaan tidak hanya mengajak 
62 Muhammad Haris, Problematika Pemberdayaan Masyarakat Miskin Jurnal At-Taghyir : Jurnal Dakwah dan Pengembangan Masyarakat Desa

Volume 2 Nomor 1 Desember 2019, h. 46-63

masyarakat untuk mengikuti program dan dipersuasi serta mentransformasi pengetahuan dan keterampilan semata. Tetapi menjawab persolan masyarakat agar kehidupannya menjadi lebih baik. Untuk itu dibutuhkan penguatan melalui pendampingan. Dampak yang muncul oleh pemahaman paradigma lama tersebut yaitu ada masyarakat yang menerapkan pengetahuan dari proses pemberdayaan ada masyarakat yang tidak menerapkan. Peserta yang menerapkannya tidak pula keseluruhan hanya sebagian saja. Sehingga output pemberdayaan tidak menghasilkan apapun.

\section{E. Kesimpulan}

Mengacu kepada permasalahan penelitian, dapat disimpulkan bahwa problematika pemberdayaan masayarakat miskin terjadi dalam proses pemberdayaan yaitu pertama, efisiensi waktu pemberdayaan yang dalam suatu kondisi masyarakat bisa mengikuti dan sebaliknya diwaktu yang lain masyarakat tidak bisa mengikuti proses pemberdayaan. Kedua, paradigma pemberdayaan yang beranggapan semua problem yang dihdapai masyarakat dijawab dengan satu program yang sama. Masyarakat bisa diintervensi, tetapi hasilnya tidak bisa menjawab kebutuhan sendiri. Ketiga, belum sesuai penerapan metode pemberdayaan di tengah keberagaman. Mampu memberikan pengetahuan dan keterampilan untuk sebagian masyarakat namun sebagian lagi tidak. Keempat, pemaksaan materi pemberdayaan tanpa melihat permasalahan, akibatnya sebagian masyarakat memiliki pengetahuan serta keterampilan, namun tidak mengubah sikap dan pola fikir. Kelima, program pemberdayaan tidak berkesinambungan. Masyarakat dilatih, dibina dan dipersuasi, tetapi tidak sampai pada keyainan bahwa mereka memiliki potensi dan kemampuan untuk menjawab kebutuhan. Selanjutnya faktor penyebab problematika pemberdayaan masyarakat miskin yaitu, belum singkronnya perencanaan pemberdayaan pusat dan praktisi. terlihat belum adanya masyarakat yang betul-betul dibina. Kemudian, belum sesuai penerapan metode pemberdayaan di tengah keberagaman. Terlihat satu metode untuk semua masyarakat tanpa melihat latar belakang dan masalah. Selanjutnya paradigma lama dalam pemberdayaan masyarakat, menyamakan kriteria kemiskinan, namun realitasnya masyarakat menghadapi permasalahan dan kebutuhan berbeda. Lebih lanjut, nilai budaya yang dipahami tertutup seperti: a). Sistem nilai dan kepercayaan yang tertutup. 
63 Muhammad Haris, Problematika Pemberdayaan Masyarakat Miskin Jurnal At-Taghyir : Jurnal Dakwah dan Pengembangan Masyarakat Desa Volume 2 Nomor 1 Desember 2019, h. 46-63

b). Pengaruh opini atau sudut pandang yang kurang tepat. c). Sikap tradisional yang berprasangka buruk terhadap hal-hal baru.

\section{Daftar Kepustakaan}

Chambers Robert. 1987. Pembangunan Desa. Jakarta : LP3ES

Dimas Alif Budi N dan M. Saleh Soeaidy, Minto Hadi, Implementasi Program Pemberdayaan Masyarakat Melalui Pelatihan Keterampilan Dasar, (Jurnal Administrasi Publik (JAP)), Vol. 1, No. 5

Haris Muhammad. 2016. Problematika Pemberdayaan Masyarakat Miskin Melalui Pusat Pelatihan Pertanian dan Peternakan(P4S) Karya Nyata Pemerintah Kabupaten Kampar. Padang: Tesis

Huraerah Abu. 2011. Pengorganisasian \& Pengembangan Masyarakat, Model \& Strategi Pembangunan Berbasis Kerakyatan. Bandung: Humaniora

Kilun Yusra, ed. 2007. Pengembangan Komunitas Muslim Kampung Badak Putih dan Kampung Duit. Jakarta: UIN Syarif Hidayatullah

Muslim Aziz. 2009. Metodologi Pengembangan Masyarakat. Yogyakarta: Teras

Nawawi Hadari dan Mimi Martini. 1994. Penelitian Terapan. Yogyakarta: Gajah Mada University Press

Rina Hardi, Opini Masyarakat Dalam Program Pusat Pelatihan Pertanian Pedesaan dan Swadaya (P4S) Pemerintah Kabupaten Kampar, (Jurnal Online Mahasiswa FISIP, Volume 1, No. 2 - oktober 2014)

Setiana L. 2005. Teknik Penyuluhan dan Pemberdayaan Masyarakat. Bogor: Bhalia Indonesia

Soleh Chabib. 2014. Dialektika Pembangunan dengan Pemberdayaan. Bandung: Fokusmedia

Sulistiyani Ambar Teguh. 2004. Kemitraan dan Model-Model Pemberdayaan. Yogyakarta: Gava Media

Sulthon Muhammad. 2003. Desain Ilmu Dakwah, Kajian Ontologis, Epistemologis dan Aksiologis. Semarang: Wali Songo Press

Susi Ratnawati. (2011). Model Pemberdayaan Perempuan Miskin Pedesaan Melalui Kewirausahaan. Jurnal Kewirausahaan, 5 (2), 1 - 10

Syukir. 1983. Dasar-Dasar Strategi Dakwah Islami. Surabaya : Al-Ikhlas

Theresia Aprillia, Dkk. 2014. Pembangunan Berbasis Masyarakat. Bandung: Alfabeta

Usman Sunyoto. 2015. Esai-Esai Sosiologi Perubahan Sosial. Yogyakarta : Pustaka Pelajar

Wrihatnolo Randy R. 2002. Manajemen Pemberdayaan. Jakarta: PT Alex Media Komputinda

Yefni, Muhammad Haris. (2019). Pemberdayaan Lingkungan Melalui Program Penyediaan Air Minum dan Sanitasi Berbasis Masyarakat(PAMSIMAS) Desa Padangmutung. Jurnal Masyarakat Madani, 4(1), 16 - 25

Zubaedi. 2013. Pengembangan Masyarakat. Jakarta: Kencana 